human amniotic fluid cells for prenatal detection of genetic disorders. Humangenetik, 114: 333 (1972).

8. Marchant, G. S.: Evaluation of methods of amniotic fluid cell culture. Amer. J. Med. Technol., 37: 391 (1971).

9. Miller, R. G., Jr.: Simultaneous Statistical Inference (McGraw-Hill, New York, 1966).

10. Milunsky, A.: The Prenatal Diagnosis of Hereditary Disorders (Charles C Thomas, Publisher, Springfield, Ill., 1973).

11. Nelson, M. M., and Emery, A. E. H.: Amniotic fluid cell culture. J. Med. Genet., 10: 19 (1973).

12. Niermeijer, M. F., Halley, D., Sachs, E., Tichelaar-Klepper, C., and Garver, K. L.: Transport and storage of amniotic fluid samples for prenatal diagnosis of metabolic diseases. Humangenetik, 20: 175 (1973).

13. Shepard, T. H.: Normal and abnormal growth patterns. In: L. I. Gardner: Endocrine and Genetic Diseases of Childhood, p. 1 (W. B. Saunders Co., Philadelphia, 1969).

14. Streeter, G. L.: Weight, sitting height, head size, foot length and menstrual age of the human embryo. Contrib. Embryo. Carnegie Inst. 11: 143 (1921).

15. To plan a supplementary experiment, it was assumed that the SD and the mean difference between 10 and $15 \%$ FCS would be of the order indicated by the preliminary experiment. It was stipulated that an increase of at least 2 colonies $/ 6 \mathrm{ml}$ would be required for significance. The mean difference of 5.12 would then have a one-sided confidence interval of approximately 3 . By inverting the usual $t$ statistic or by use of Studentized range graph paper, we estimated that another experiment with approximately 40 blocks, using only 10 and $15 \%$ FCS, should detect such a difference at a 0.05 level of significance.

16. Wheaton Glass Co., Millville, N. Y., catalog no. 20545.

17. Falcon Plastics, Oxnard, Calif, catalog no. 3001

18. Wedco, Inc., Silver Springs, Md., model no. 2-17M.

19. Grand Island Biological Co., Grand Island, N.Y.

20. Radiometer, Copenhagen, pH meter no. 22, microelectrode no. 5021 , London Co., Cleveland, Ohio.

21. These studies were reviewed and approved by the Committee on Investigations Involving Human Subjects, University of Rochester School of Medicine and Dentistry, Rochester, N. Y.

22. We wish to thank the numerous obstetricians and nurses who provided us with AF specimens.

23. This work was supported by a grant from The John A. Hartford Foundation, Inc., and by NIH/GSRR RR 05403. Part of the work was performed in facilities of the United States Atomic Energy Commission at the University of Rochester Atomic Energy Project and has been assigned Report no. UR-3490-496.

24. Requests for reprints should be addressed to: R. Doherty, M. D., Department of Pediatrics, University of Rochester School of Medicine, Rochester, N. Y. 14642 (USA).

25. Accepted for publication July 2, 1974
Developmental biochemistry lecithin

lung

\title{
Studies on the Biosynthesis of Disaturated Lecithin of the Lung: The Importance of the Lysolecithin Pathway
}

\author{
MIKKO HALLMAN AND KARI RAIVIO(31) \\ Department of Pediatrics, University of Helsinki, Helsinki, Finland
}

\section{Extract}

The formation of disaturated lecithin in lung slices obtained from adult rabbit was studied. Radioactive precursors of the known biosynthetic pathways of lecithin were used.

Cytidine diphospho-(methyl- $\left.{ }^{14} \mathrm{C}\right)$ choline (CDP- $\left({ }^{14} \mathrm{C}\right)$ choline) was the marker of the choline incorporation pathway. The label rapidly appeared in lecithins and subsequently in lysolecithin. As a function of time, the ratio of label in disaturated to total lecithin increased significantly. When the slices were preincubated with the radioactive precursor and then with excess nonradioactive precursor, the fraction of total lecithin radioactivity associated with disaturated species increased from 14.2 to $24.0 \%$ in $120 \mathrm{~min}$.

Lecithin labeled with $\left(1(3)-{ }^{3} \mathrm{H}\right)$ glycerol and $\left(1-{ }^{14} \mathrm{C}\right)$ palmitic acid and containing a high percentage of unsaturated fatty acids was incubated with lung slices. After $1 \mathrm{hr}$, the ratio of ${ }_{14} \mathrm{C}$ label in disaturated to total lecithin nearly doubled, and ${ }^{14} \mathrm{C}$ and ${ }^{3} \mathrm{H}$ in disaturated lecithin increased by $58 \%$ and $21 \%$, respectively.

After $60 \mathrm{~min}$ of incubation of liver slices with 1-acyl-2-lyso- lecithin labeled with (1(3)- $\left.{ }^{3} \mathrm{H}\right)$ glycerol and $\left(1-{ }^{14} \mathrm{C}\right)$ palmitic acid, the ratio of the ${ }^{3} \mathrm{H}$ label in lecithin to lysolecithin was 2.0. In disaturated lecithin the ratio of ${ }^{3} \mathrm{H}$ to ${ }^{14} \mathrm{C}$ radioactivity was less than half of that in lysolecithin, and $61 \%$ of ${ }^{14} \mathrm{C}$ radioactivity was associated with fatty acid esterified to position 2.

Using $S$-adenosyl (methyl ${ }^{3} \mathbf{H}$ ) methionine or phosphatidylethanolamine labeled with $\left(1(3)-{ }^{3} \mathrm{H}\right)$ glycerol and $\left(1-{ }^{14} \mathrm{C}\right)$ palmitic acid as precursors, the radioactivity appeared rapidly and almost exclusively in unsaturated lecithins and reached a maximum after $60 \mathrm{~min}$ of incubation. Thereafter the specific activity of lecithin fell to half of its maximal value with in $\mathbf{9 0}$ min. Lysolecithin became heavily labeled.

The data suggest that in lung slices obtained from adult rabbit a modification of the lecithin fatty acids takes place. Hydrolysis of an unsaturated fatty acid esterified to position 2 is followed by reacylation with a saturated fatty acid, possibly by a transacylation reaction from position 1 of another 1-acyl-2-lysolecithin molecule, to form disaturated lecithin. The choline incorporation pathway of de novo formation of lecithin appears to combine with such a lysolecithin "loop" to 
form lecithin, which is considered to have better surfactant properties than unsaturated lecithin.

\section{Speculation}

Different tissues and, presumably, different cells within the same tissue roduce lecithins with different fatty acid composition and different surfactant properties. Although lung slices contain a heterogenous complement of cells, with variable metabolic capabilities, the existence of another pathway for the synthesis of disaturated lecithin is of potential functional significance. Further evaluation of the quantitative aspects of the "lysolecithin loop" must await the isolation and study of surfactant-producing type II alveolar cells.

The principal function of the surfactant lining the lung alveoli is to decrease the surface tension of the air-liquid interface and so to prevent the collapse of the alveoli. The main component of the surfactant seems to be disaturated lecithin, mainly dipalmitoyl lecithin, which is particularly effective in lowering surface tension $(6,9,19)$. In the lung unusually large amounts of lecithin containing saturated fatty acids are present. It has been shown that the surfactant obtained from endobronchial wash accurately reflects the surface active material of the whole lung (9). In idiopathic respiratory distress syndrome of the neonate and perhaps in other conditions too, there seems to be a deficient production of surfactant lecithin $(5,11,16,18)$.

The aim of the present study was to explore the pathways of synthesis of disaturated lecithin in the lung. Special attention was focused on the possibility of surfactant production through modification of preformed lecithin: removal of an unsaturated fatty acid followed by reacylation by a saturated fatty acid $(1,14)$. Although the reactions involved have each been separately demonstrated in mammalian systems $(7,19)$, an attempt at evaluation of the whole sequence in pulmonary tissue seemed warranted.

\section{METHODS}

\section{PREPARATION AND INCUBATION OF TISSUE}

Adult female rabbits were decapitated under light ether anesthesia. Samples of lung tissue which weighed $1-2 \mathrm{~g}$ were rapidly removed and chilled in ice-cold Krebs-Ringer bicarbonate medium. Excess blood was removed by several washings of the tissue. Lung slices were prepared using a Stadie-Riggs slicer (22). Tissue hom ogenates in Krebs-Ringer bicarbonate medium were obtained using a Potter-Elvehjem homogenizer, followed by filtering through cheesecloth. The incubation medium was Krebs-Ringer bicarbonate containing $6.9 \mathrm{mM}$ glucose. When lysolecithin was the radioactive precursor, $3.5 \mathrm{mg} / \mathrm{ml}$ serum albumin (fraction $V$ from bovine serum (23)) was added. Incubation took place at $37^{\circ}$ with shaking in flat-bottomed flasks. Tissue slices which weighed $60-80 \mathrm{mg}$ of homogenate obtained from $60 \mathrm{mg}$ tissue were added to $0.7 \mathrm{ml}$ medium. Constant slow current of $95 \%$ $\mathrm{O}_{2}-5 \% \mathrm{CO}_{2}$ came through a hole in the cover of the flask during incubation.

\section{LIPID ANALYSIS}

After incubation with radioactive precursors, the slices were rinsed with cold medium, then $20 \mathrm{ml}$ chloroform-methanol (2:1) were added to each sample and the lipids were extracted by the method of Folch et al. (8). Homogenization of slices and re-extraction yielded less than $1 \%$ of the amount of phospholipid initially obtained; hence, re-extraction was omitted. Because of the small amounts of lysolecithin in the tissue, unlabeled lysolecithin carrier was added. Phospholipids were isloated by means of two-dimensional thin layer chromotography (21). Commercial plates (24) were used. The first dimension was developed twice in chloroform-methanol-7 $\mathrm{N}$ aqueous ammonia $(65: 20: 4)$ and the second in chloroformacetone-methanol-acetic acid-water (50:20:10:10:5). No hydrolysis of doubly labeled lecithin could be shown during thin layer chromotography. Phospholipids were located by brief exposure to iodine vapor, or in some cases using dichlorfluorescein (3). The results obtained were independent of the localization method used.

Disaturated lecithins were isolated essentially as described by Mason and associates (17). The unsaturated lecithins were adducted in $1 \mathrm{ml}$ saturated mercuric acetate overnight. After removing excess mercuric acetate, the adducted lecithins were separated from disaturated lecithins by one-dimensional chromatography in silica gel plates using chloroform-methanol$7 \mathrm{~N}$ aqueous ammonia $(65: 20: 4)$. The amount of unsaturated lecithins (i.e., lecithins that contained one or several double bonds in fatty acid or acids esterified to the glycerol portion) was calculated by subtraction of the amount of disaturated lecithin from that of total lecithin.

Phospholipids were removed from the gel as follows. The appropriate area was scraped off the plate, $5 \mathrm{ml}$ chloroformmethanol $(1: 1)$ were added and the mixture was sonicated for $1 \mathrm{~min}$. Thereafter, the gel was twice washed with chloroformmethanol. In six experiments using lecithin, 1-acyl-2lysolecithin, and phosphatidyl ethanolamine, an average of $92 \%$ of phospholipids were eluted. Solvents used were anaerobic and contained $0.004 \%$ of 2,6-di-tert-butyl-p-cresol to prevent oxidation of unsaturated fatty acids. Evaporations were performed under nitrogen.

Phospholipid phosphorus was measured according to the method of Bartlett (4). All chemicals used were of analytical grade.

\section{ISOTOPE TECHNIQUE}

$S$-Adenosyl-L-(methyl- $\left.{ }^{3} \mathrm{H}\right)$ methionine $(500 \mathrm{mCi} / \mathrm{mmol})$, (1(3) $\left.{ }^{3} \mathrm{H}\right)$ glycerol $(5.5 \mathrm{Ci} / \mathrm{mmol})$, and $\left(1-{ }^{14} \mathrm{C}\right)$ palmitic acid $(59$ $\mathrm{mCi} / \mathrm{mmol})$ were purchased from the Radiochemical Centre (25). CDP- $\left({ }^{14} \mathrm{C}\right)$ choline $(41 \mathrm{mCi} / \mathrm{mmol})$ was a gift of $\mathrm{NEN}$ Chemicals G.m.b.H. (26). Doubly labeled lecithin was prepared from rat liver. A young rat, aged 12 days, was injected intraperitoneally with $0.20 \mathrm{mCi}\left(1-{ }^{14} \mathrm{C}\right)$ palmitic acid, and complexed with serum albumin and $1.2 \mathrm{mCi}$ of (1(3)${ }^{3} \mathrm{H}$ )glycerol $90 \mathrm{~min}$ before decapitation. Lecithin and phosphatidylethanolamine were extracted from the liver and purified as described above. Lecithin contained 309 and 270 $\mathrm{cpm} / \mathrm{nmol}$ of ${ }^{14} \mathrm{C}$ and ${ }^{3} \mathrm{H}$ counts, respectively. Four per cent of ${ }^{3} \mathrm{H}$ label was associated with the fatty acid esterified in position 2. Phosphatidylethanolamine contained $107 \mathrm{cpm}^{14} \mathrm{C}$ and $109 \mathrm{cpm}{ }^{3} \mathrm{H}$ activity/nmol. 1-Acyl-2-lysolecithin and 1-acyl-2-lysophosphatidyl ethanolamine were prepared from these compounds as follows: $3 \mu \mathrm{mol}$ labeled lecithin or $1 \mu \mathrm{mol}$ labeled phosphatidyl ethanolamine were incubated for 120 $\mathrm{min}$ in an anaerobic reaction vessel containing the following in a 7-ml solution: $0.7 \mathrm{mmol} \mathrm{CaCl}_{2}$ and $0.7 \mathrm{mmol} \mathrm{N}$-tris-(hydroxymethyl)methyl-2-aminoethane sulfonic acid (27), $\mathrm{pH}$ 6.8 , to which was added $0.1 \mathrm{mg}$ phospholipase $\mathrm{A}_{2}$ (phosphatide acyl-hydrolase, EC. 3.1.1.4 (28)). The solution was overlaid with $20 \mathrm{ml}$ ethyl ether. Lysophospholipid formed in the lower phase was washed three times with ether and finally isolated using thin layer chromatography. Lysolecithin used in experiments contained $150 \mathrm{cpm}{ }^{14} \mathrm{C}$ and $135 \mathrm{cpm}^{3} \mathrm{H}$ radioactivity/nmol. The corresponding activities in lysophosphatidyl ethanolamine were 99 and $116 \mathrm{cpm}$.

The distribution of the radioactivity between positions 1 and 2 of lecithin was measured essentially by the same procedure used in the preparation of lysolecithin. Carrier lecithin was added. After pholpholipase $\mathrm{A}_{2}$ treatment, the radioactivities were measured in the combined ether phase and in the material insoluble in ether.

Radioactivity determinations were made with a Wallac 
SC-20 liquid scintillation spectrometer using toluene-based scintillator. The ${ }^{3} \mathrm{H}$ and ${ }^{14} \mathrm{C}$ activities were calculated according to the channels ratio method. Quenching was corrected for by internal standardization. The counting efficiencies for ${ }^{14} \mathrm{C}$ and ${ }^{3} \mathrm{H}$ were $35 \%$ and $20 \%$, respectively.

\section{RESULTS}

\section{CHOLINE INCORPORATION PATHWAY}

Preliminary studies were performed to establish suitable conditions for the incorporation of $\mathrm{CDP}_{-}\left({ }^{14} \mathrm{C}\right)$ choline into lung phospholipids. In all experiments, $0.6 \mu \mathrm{Ci}$ isotope was used. The rate of incorporation by lung homogenate in Krebs-Ringer phosphate was $0.3 \mathrm{cpm} / \mathrm{nmol}$ lecithin $/ \mathrm{hr}$, whereas the corresponding figures for lung tissue slices were $10.2 \mathrm{cpm} / \mathrm{nmol} / \mathrm{hr}$ in Krebs-Ringer phosphate and 29.8 $\mathrm{cpm} / \mathrm{nmol} / \mathrm{hr}$ in Krebs-Ringer bicarbonate. The negligible rate of incorporation in the homogenate is apparently due to the marked inhibition of CDP-choline:1,2-diglyceride choline phosphotransferase by $\mathrm{Ca}^{+}$, present in the medium (15). For further experiments the slice system was adopted. Preincubation of the slices for $30 \mathrm{~min}$ before the addition of isotope did not alter the results obtained without preincubation. Since transport per se was not studied, our data give no clues to the question whether CDP-choline entered the slices as such or whether it was split before transport.

The time course of the incorporation of $\mathrm{CDP}_{-}\left({ }^{14} \mathrm{C}\right)$ choline into lecithin and lysolecithin is shown in Figure 1. The specific activity of lecithin increased up to $100 \mathrm{~min}$ of incubation and stabilized thereafter. Between 30 and $100 \mathrm{~min}$, the apparent rate of lecithin synthesis via this pathway was $8.4 \mathrm{nmol} / \mathrm{hr} /$ $\mu \mathrm{mol}$ phospolipid-P. However, since the specific activity of the precursor, be it CDP- $\left({ }^{14} \mathrm{C}\right)$ choline itself or $\left({ }^{14} \mathrm{C}\right)$ choline after breakdown, was not determined, the term "apparent rate of synthesis" has been used and it represents a minimum estimate of the true rate. After short periods of incubation, most of the label was associated with unsaturated lecithins, but as a function of time the ratio of radioactivity in disaturated lecithins to that in total lecithin increased significantly (Fig. 1). The radioactivity in lysolecithin increased at a slower rate than that in lecithin, but the sensitivity of the methods did not permit the determination of the specific activity of lysolecithin (expressed on the basis of total phospholipid phosphorus, Fig. 1).

In a separate set of experiments, lung slices were preincubated with $\operatorname{CDP}-\left({ }^{14} \mathrm{C}\right)$ choline for $15 \mathrm{~min}$ and thereafter the slices were transferred to a new medium containing $1.4 \mu \mathrm{mol}$ unlabeled CDP-choline. The radioactivities in total and disaturated lecithins after this puise labeling are indicated in Table 1. The incorporation into total lecithins continued at a low rate ( $c f$. Fig. 1), and in the course of time the fraction of label in disaturated lecithins increased from $14.2 \%$ to $24.0 \%$ of the total.

\section{METHYLATION PATHWAY}

Preliminary studies indicated that both slices and homogenates of lung tissue were active in incorporating label from $S$-adenosyl-L-(methyl- $\left.{ }^{3} \mathrm{H}\right)$ methionine into phospholipids. Again, it is possible that the precursor was split before transport into the slices. On the other hand, labeled phosphatidylethanolamine was not significantly utilized by tissue slices, presumably because of poor permeability, but was a good precursor of lecithins in homogenate experiments.

Table 2 shows the incorporation of radioactivity from the precursors of the methylation pathway into the two classes of lecithin studied, as well as into lysolecithin. The fraction of label associated with disaturated lecithins was consistently less than $7 \%$ of total lecithin radioactivity after $60 \mathrm{~min}$ of incubation. Lysolecithin was significantly labeled, containing $23-39 \%$ of lecithin radioactivity. When phosphatidylethanolamine labeled with $\left({ }^{14} \mathrm{C}\right)$ palmitate and $\left({ }^{3} \mathrm{H}\right)$ glycerol was the precursor, the ${ }^{3} \mathrm{H} /{ }^{14} \mathrm{C}$ ratio remained unaltered in both classes of lecithins. Table 2 also shows that neither lecithin nor lysolecithin was significantly labeled by lysophosphatidylethanolamine.

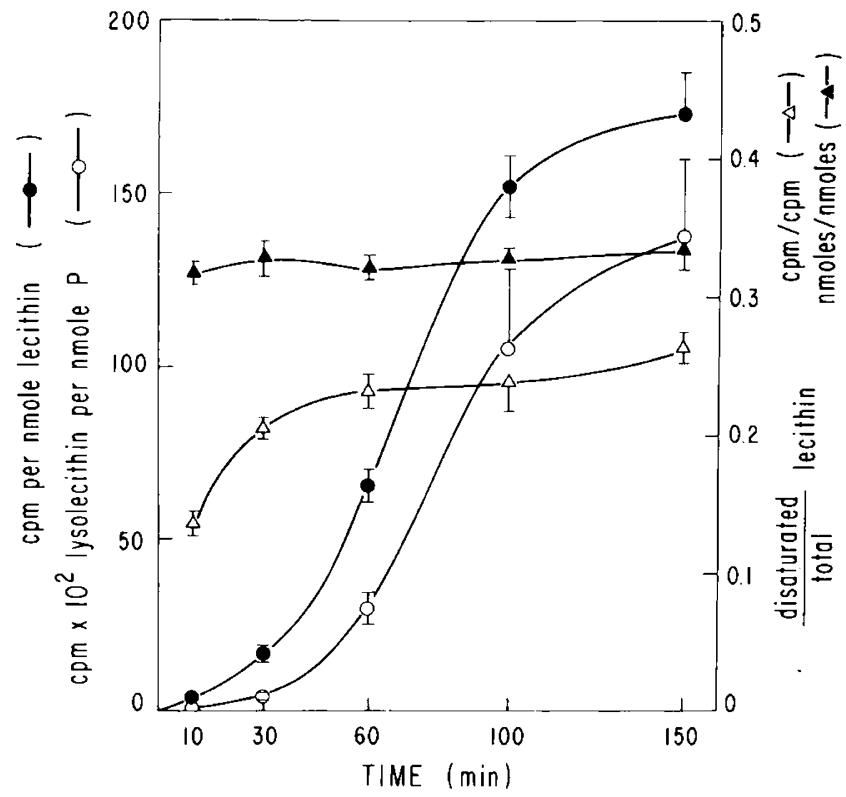

Fig. 1. Incorporation of radioactivity from cytidine diphospho(methyl ${ }^{-14} \mathrm{C}$ )choline $(0.6 \mu \mathrm{Ci})$ into total lecithin and lysolecithin, and into disaturated versus total lecithin, in rabbit lung slices. For experimental details, see text. The specific activity of lecithin is given, whereas the data on lysolecithin represent total counts incorporated per nmole phospholipid phosphorus. The results are expressed as means \pm SE of four experiments.

Table 1. Radioactivity in total and disaturated lecithins of lung slices prelabeled for 15 min with $0.6 \mu \mathrm{Ci}$ cytidine diphospho-(methyl- $\left.{ }^{14} \mathrm{C}\right)$ choline $\left(C D P-\left({ }^{14} \mathrm{C}\right)\right.$ choline) and then incubated in fresh medium containing unlabeled CDP-choline $(2 \mathrm{mM})$ for periods shown

Total activity, cpm

Specific activity, cpm/nmol

\begin{tabular}{|c|c|c|c|c|c|c|}
\hline Time, min & Total & Disaturated & $\begin{array}{c}\text { Disaturated/ } \\
\text { total }\end{array}$ & Total & Disaturated & $\begin{array}{c}\text { Disaturated/ } \\
\text { total }\end{array}$ \\
\hline 0 & 1,230 & 175 & 0.14 & 5.12 & 2.26 & 0.44 \\
\hline 40 & 2.092 & 341 & 0.16 & 9.09 & 3.93 & 0.43 \\
\hline 60 & 2,358 & 437 & 0.19 & 10.16 & 6.20 & 0.61 \\
\hline 120 & 3,295 & 636 & 0.19 & 15.70 & 9.63 & 0.61 \\
\hline
\end{tabular}


Table 2. Radioactivity in total and disaturated lecithins and in lysolecithin after incubation of lung homogenates with either S-adenosyl-(methyl- $\left.{ }^{3} \mathrm{H}\right)$ methionine $(S A M, 3.1 \mu C i)$, doubly labeled phosphatidylethanolamine $\left(P E, 18,090 \mathrm{cpm}{ }^{14} \mathrm{C}\right)$ or doubly labeled lysophosphatidylethanolamine (LPE, 3,585 $\mathrm{cpm}^{14} \mathrm{C}^{1}$

Total incorporation

Lecithins

\begin{tabular}{|c|c|c|c|c|c|c|c|}
\hline Precursor & $\mathrm{N}$ & Total & Disaturated & $\begin{array}{l}\text { Disaturated/ } \\
\text { total }\end{array}$ & Lysolecithin & Total & Disaturated \\
\hline$\left({ }^{3} \mathrm{H}\right) \mathrm{SAM}$ & 3 & $3,850 \pm 342$ & $74 \pm 42$ & 0.02 & $881 \pm 99$ & $13.44 \pm 0.91$ & $0.71 \pm 0.51$ \\
\hline${ }^{3} \mathrm{H} /{ }^{14} \mathrm{C}$ & & $0.85 \pm 0.03$ & $0.44 \pm 0.09$ & & $0.88 \pm 0.05$ & & \\
\hline$\left({ }^{14} \mathrm{C}\right) \mathrm{LPE}$ & 2 & 38 & 10 & & 10 & 0.13 & \\
\hline
\end{tabular}

${ }^{1}{ }^{14} \mathrm{C}$ data and ${ }^{3} \mathrm{H} /{ }^{14} \mathrm{C}$ ratios are given for PE, only ${ }^{14} \mathrm{C}$ incorporation for $\mathrm{LPE}$. Mean $\pm \mathrm{SE}$ are indicated.

The time course of the labeling of lecithins and lysolecithin by $S$-adenosyl-L-(methyl- $\left.{ }^{3} \mathrm{H}\right)$ methionine in lung slices is given in Figure 2. The specific activity of lecithin increased rapidly up to a maximum at $60 \mathrm{~min}$, whereafter it declined to $46 \%$ of the maximum at $150 \mathrm{~min}$. The explanation for this decline is a problem which was not pursued further, since the pathway seemed to be of secondary importance to surfactant production. However, our findings with the other precursors suggest that the viability of the slices was not the limiting factor. During the first hour, the apparent rate of lecithin synthesis was $1.1 \mathrm{nmol} / \mu \mathrm{mol}$ phospholipid-P. Lysolecithin became labeled somewhat later and to a smaller extent than lecithin, and it, too, exhibited a decline in the course of time. Again, it was not possible to measure the amount and hence the specific activity of lysolecithin. The radioactivity incorporated into disaturated lecithins was consistently less than $2 \%$ of total lecithin radioactivity.

\section{LYSOLECITHIN PATHWAY}

The rapid appearance of radioactivity in lysolecithin and the apparent increase in the degree of saturation of lecithin, seen in the CDP-choline experiments, suggested to us that a pathway exists in lung tissue, the function of which is to alter the fatty acid composition of preformed lecithin. To explore this hypothesis further, lysolecithin labeled with $\left({ }^{14} \mathrm{C}\right)$ palmitate and $\left({ }^{3} \mathrm{H}\right)$ glycerol was incubated with lung slices (Table 3 ). After $60 \mathrm{~min}, 43 \%$ of ${ }^{3} \mathrm{H}$ and $55 \%$ of ${ }^{14} \mathrm{C}$ radioactivity was recovered in lecithin plus lysolecithin, and of this total, $67-73 \%$ was in lecithin. The apparent rate of lecithin formation was $13.0 \mathrm{nmol} / \mathrm{hr} / \mu \mathrm{mol}$ phospholipid-P. Disaturated lecithin contained only $20 \%$ of the ${ }^{3} \mathrm{H}$ in total lecithin, but about $38 \%$ of the ${ }^{14} \mathrm{C}$. This relative enrichment of ${ }^{14} \mathrm{C}$ radioactivity, which was contained in the fatty acid moiety of the precursor, was also reflected in the markedly lower ${ }^{3} \mathrm{H} /{ }^{14} \mathrm{C}$ ratio in disaturated lecithin as compared with the unsaturated species or the precursor.

Phospholipase $\mathrm{A}_{2}$ digestion of disaturated lecithin released $61 \%$ of ${ }^{14} \mathrm{C}$ radioactivity to the ether phase. According to this, more than half of the labeled fatty acids were bound to position 2 of disaturated lecithin.

To study the possibility that the $\left({ }^{14} \mathrm{C}\right)$ palmitate in position 2 of lecithin was derived from hydrolyzed lysolecithin, a further experiment was conducted by adding $50 \mu \mathrm{g}$ (195 nmol) of unlabeled palmitate, complexed with $5 \mathrm{mg}$ defatted albumin (other conditions as shown in Table 3 ). Under these conditions, $30 \%$ of ${ }^{14} \mathrm{C}$ label in lecithin was associated with position 2, whereas in the absence of added palmitate the corresponding fraction was $39 \%$. Thus the distribution of label between the positions 1 and 2 of lecithin was little affected by the addition of excess unlabeled palmitate.

The modification of preformed lecithin by lung tissue slices was further examined by using lecithin prelabeled with

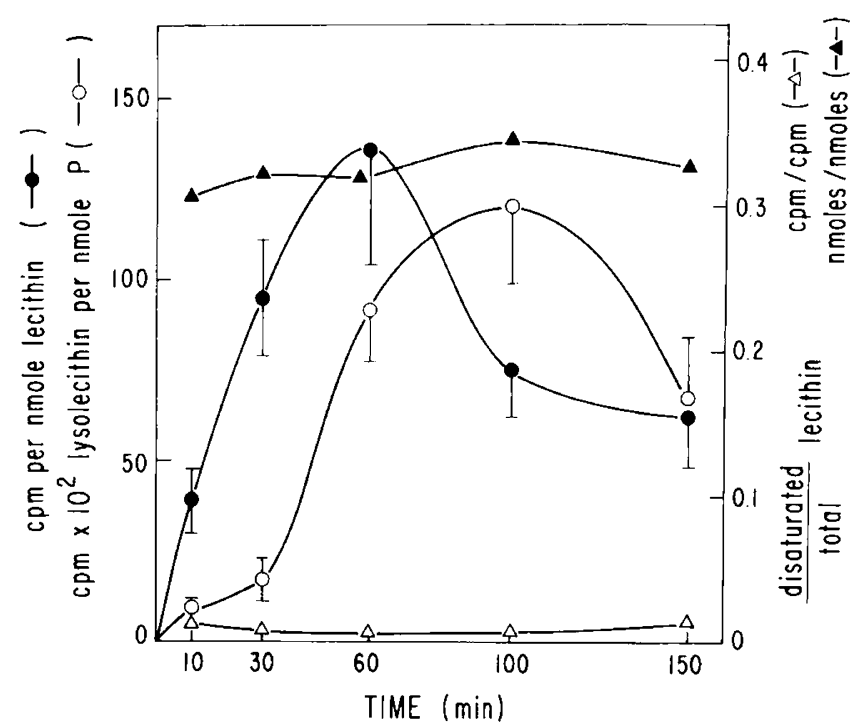

Fig. 2. Incorporation of radioactivity from $S$-adenosyl-(methyl $\left.{ }^{3} H\right)$ methionine $(3.1 \mu \mathrm{Ci})$ into total lecithin and lysolecithin, and into disaturated versus total lecithin in rabbit lung slices in four experiments. For experimental details see text. The data are as in Figure 1.

Table 3. Radioactivity in total and disaturated lecithins and lysolecithin after 60 min of incubation of lung slices with

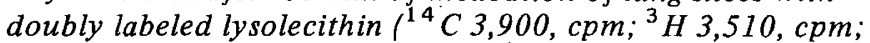
ratio 0.90$)^{1}$

Lecithins

\begin{tabular}{lcccc}
\cline { 2 - 3 } & Total & Disaturated & $\begin{array}{c}\text { Disaturated/ } \\
\text { total }\end{array}$ & Lysolecithin \\
\hline${ }^{14} \mathrm{C}$ & $1,589 \pm 101$ & $601 \pm 58$ & $0.38 \pm 0.02$ & $567 \pm 63$ \\
${ }^{3} \mathrm{H}$ & $1,018 \pm 68$ & $202 \pm 37$ & $0.20 \pm 0.02$ & $502 \pm 65$ \\
${ }^{3} \mathrm{H} /{ }^{14} \mathrm{C}$ & $0.64 \pm 0.03$ & $0.34 \pm 0.04$ & & $0.89 \pm 0.04$ \\
\hline
\end{tabular}

${ }^{1}$ Results are means $\pm \mathrm{SE}$ of four experiments.

$\left({ }^{14} \mathrm{C}\right)$ palmitate and $\left({ }^{3} \mathrm{H}\right)$ glycerol. After $60 \mathrm{~min}$ of incubation, $85 \%$ of the ${ }^{14} \mathrm{C}$ and $82 \%$ of the ${ }^{3} \mathrm{H}$ was recovered in lecithin plus lysolecithin, which had become labeled to some extent (Table 4). Despite the decrease in total lecithin radioactivity, there was a net increase in both ${ }^{3} \mathrm{H}$ and ${ }^{14} \mathrm{C}$ associated with disaturated lecithin, but in both classes of lecithins the ${ }^{3} \mathrm{H} /{ }^{14} \mathrm{C}$ ratio changed only slightly. 
Table 4. Radioactivity in total and disaturated lecithins and lysolecithin after 60 min of incubation of lung slices with doubly labeled lecithin ${ }^{1}$

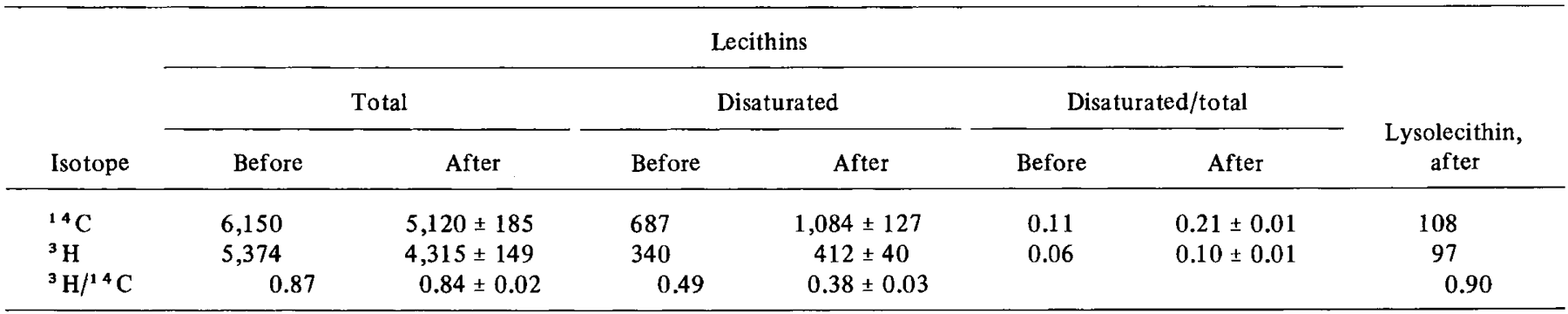

${ }^{1}$ Precursor counts per minute and the ${ }^{3} \mathrm{H} /{ }^{14} \mathrm{C}$ ratios are indicated as well as the counts per minute for the two isotopes and their ratios in the compounds after incubation. Results are means $\pm \mathrm{SE}$ of four experiments.

\section{DISCUSSION}

Mammalian lung tissue possesses two enzymatic pathways for the de novo synthesis of lecithin: the choline incorporation pathway and the methylation pathway. Available evidence suggests that the former is the predominant route, at least during postnatal life (13). Both pathways are capable of producing disaturated lecithin, i.e., lecithin with two saturated fatty acids, which is the species with outstanding surfactant properties. It has been suggested that dipalmitoyl lecithin is produced mainly by the choline incorporation pathway and could serve as marker compound for this pathway, and that the same would apply to palmitoylmyristoyl lecithin and the methylation pathway $(11,12)$. No hypotheses have been presented to explain such specificity in enzymologic terms. However, in addition to the de novo pathways of lecithin formation, the reversible breakdown of the fatty acid moieties of lecithin can further modify the fatty acid pattern (14). The importance of these pathways in the formation of surfactant lecithin in the lung is only partially understood $(1,2,10)$. According to the data of Frosolono et al. (10), lysolecithin is acylated with acyl-CoA in lung microsomes. However, the specific activities with unsaturated fatty acids were higher than with saturated fatty acids, which suggests that this pathway principally produces lecithin species needed for purposes other than surfactant function.

Our data suggest that a molecule of disaturated lecithin does not necessarily represent an end product of either de novo pathway but may represent the product of a remodeling process as follows:

$\begin{array}{lll}\text { C-FA (sat) } & \text { C-FA (sat) } & \text { C-FA (sat) } \\ \text { C-FA (unsat) } & \text { C-OH } & \text { C-FA (sat) } \\ \text { C-phosphocholine } & \text { C-phosphocholine } & \text { C-phosphocholine }\end{array}$

This hypothesis is based on the following findings.

1. Both the choline incorporation pathway and the methylation pathway lead to significant labeling of lysolecithin. The time course of this labeling is consistent with the notion that lecithin is the precursor of this lysolecithin (Figs. 1 and 2).

2 . With CDP-choline as the precursor, there is a time-dependent increase in the labeling of disaturated relative to unsaturated lecithin. This was also demonstrated after the pulse labeling of tissue with the radioactive isotope (Table 1). This serves as evidence against the possibility that the timedependent change in the distribution of label between lecithin species is due to factors other than remodeling of lecithin (e.g., differences in the rate of incorporation of various diglyceride species or in the pool sizes between individual cells). Artifacts due to damaged tissue or disrupted cells do not seem likely, since the incorporation of radioactivity from CDP- $\left({ }^{14} \mathrm{C}\right)$ choline would be inhibited in a similar way to our findings using homogenates, presumably due to the presence of $\mathrm{Ca}^{+t}$ ions (15).

3. Doubly labeled 1-acyl-2-lysolecithin is effectively trans- formed into lecithin. In the process, the ${ }^{14} \mathrm{C}$ activity associated with the fatty acid (palmitate) moiety is enriched relative to the ${ }^{3} \mathrm{H}$. More than half of ${ }^{14} \mathrm{C}$ radioactivity was associated with the fatty acid esterified to position 2 of disaturated lecithin. Furthermore, the addition of an excess of unlabeled palmitate to the incubation medium did not markedly change the distribution of label between positions 1 and 2 of lecithin. Therefore, it seems that principally transacylation between two lysolecithin molecules rather than direct acylation of lysolecithin is taking place. Consistent with this mechanism is also the low recovery of ${ }^{3} \mathrm{H}$ radioactivity in lecithin plus lysolecithin, the rest presumably accumulating in glycerophosphorycholine, which was not measured (Table 3). On the other hand, the present experiments do not exclude the possibility that some disaturated lecithin is derived by straight acylation of lysolecithin.

4. Doubly labeled lecithin, when incubated with lung slices, is modified so that the radioactivity in the disaturated fraction shows a net increase, and lysolecithin becomes labeled. The ${ }^{3} \mathrm{H} /{ }^{14} \mathrm{C}$ ratio in lysolecithin was similar to the corresponding ratio in lysolecithin obtained by phospholipase $A_{2}$ treatment (Table 4). This is in agreement with the finding of high activity of phospholipase $A_{2}$ in the lung (20).

Thus, these observations suggest the presence of a deacylation-reacylation "loop" in the lung tissue of the adult rabbit, with the possible function of improving the surfactant qualities of preformed lecithin. The data also suggest that the choline incorporation pathway combines with the lysolecithin "loop" to form disaturated lecithin, whereas the role of the methylation pathway seems to be less important in this respect. Our data do not permit calculations about the quantitative importance of the lysolecithin pathway. In any case, the assumption that a molecule of lecithin with a specific fatty acid composition is a marker for only a specific de novo synthetic pathway seems to be unwarranted. Further studies with isolated alveolar type II cells, specific for surfactant production, are needed to firmly establish the role of the various pathways in the biosynthesis of surfactant lecithin.

\section{SUMMARY}

In studies of lecithin synthesis in rabbit lung slices, evidence was obtained for the existance of a deacylation-reacylation "loop," which removes an unsaturated fatty acid from lecithin and substitutes it with a saturated fatty acid. The function of such a pathway seems to be the production of disaturated lecithin, which has generally been found to have better surfactant qualities than unsaturated lecithin.

\section{REFERENCES AND NOTES}

1. Abe, M., Akino, T., and Ohno, K.: The formation of lecithin from lysolecithin in rat lung supernatant. Biochim. Biophys. Acta, 280: 275 (1972).

2. Akino, T., Abe, M., and Arai, T.: Studies on the biosynthetic 
pathways of molecular species of lecithin by rat lung slices. Biochim. Biophys. Acta, 248: 274 (1971).

3. Arvidson, G. A. E.: Structural and metabolic heterogeneity of rat liver glycerophosphatides. Eur. J. Biochem, 4: 478 (1968).

4. Bartlett, G. R.: Phosphorus assay in column chromatography. J. Biol. Chem., 234: 466 (1959).

5. Brumley, G. W., Cernick, V., Hodson, W. A., Normand, C., Fenner, A., and Avery, M. E.: Correlations of mechanical stability, morphology, pulmonary surfactant, and phospholipid content in the developing lamb lung. J. Clin. Invest., 46: 863 (1967).

6. Clements, J. A., Nellenbogen, J., and Trahan, H. J.: Pulmonary surfactant and evolution of the lungs. Science, 169: 603 (1970).

7. Erbland, J. F., and Marinetti, G. V.: The enzymatic acylation and hydrolysis of lysolecithin. Biochim. Biophys. Acta, 105: 128 (1965).

8. Folch, J., Leeds, M., and Sloane-Stanley, G. H.: A simple method for the isolation and purification of total lipids from animal tissues. J. Biol. Chem., 226: 497 (1957).

9. Frosolono, M. F., Charms, B. L., Pawlowski, R., and Slivka, S.: Isolation, characterization and surface chemistry of a surfaceactive fraction from dog lung. J. Lipid Res., 11: 439 (1970).

10. Frosolono, M. F., Slivka, S., and Charms, B. L.: Acyl transferase activities in dog lung microsomes. J. Lipid Res., 12: 96 (1971).

11. Gluck, L., Kulovich, M. F., Eidelman, H. I., Cordero, L., and Khazin, A. F.: Biochemical development of surface activity in mammalian lung. IV. Pulmonary lecithin systhesis in the human fetus and newborn and etiology of the respiratory distress syndrome. Pediat. Res., 6: 81 (1972).

12. Gluck, L., Landowne, R. A., and Kulovich, M. V.: Biochemical development of surface activity in mammalian lung. III. Structural changes in lung lecithin during development of rabbit fetus and newborn. Pediat. Res., 4: 352 (1970).

13. Gluck, L., Sribney, M., and Kulovich, M. V.: The biochemical development of surface activity in mammalian lung. II. The biosynthesis of phospholipids in the lung of the developing rabbit fetus and newborn. Pediat. Res., 1: 247 (1967).

14. Hill, E. E., and Lands, W. E. M.: Phospholipid metabolism. In: S. J. Wakil: Lipid Metabolism, Ed. 1, p. 185 (Academic Press, New
York, 1970).

15. Kennedy, E. P., and Weiss, S. B.: The function of cytidine coenzymes in the biosynthesis of phospholipides. J. Biol. Chem., 222: 193 (1953).

16. Kikkawa, Y., Motoyama, E. K., and Gluck, L.: Study of the lungs of fetal and newborn rabbits: morphologic, biochemical and surface physical development. Amer. J. Pathol., 52: 177 (1968).

17. Mason, R. J., Huber, G., and Vaughan, M.: Synthesis of dipalmitoyl lecithin by alveolar macrophages. J. Clin. Invest., 51: 68 (1972).

18. Morgan, T. E., and Edmunds, L. H., Jr.: Pulmonary artery occlusion. III. Biochemical alterations. J. Appl. Physiol., 22: 1012 (1967).

19. Morgan, T. E., Finley, T. N., Huber, G. L., and Fialkow, H.: Alterations in pulmonary surface active lipids during exposure to increased oxygen tension. J. Clin. Invest., 44: 1737 (1965).

20. Ohta, M., Hasegawa, H., and Ohmo, K.: Calcium independent phospholipase $A_{2}$ activity in rat lung supernatant. Biochim. Biophys. Acta, 280: 552 (1972).

21. Renkonen, O., Gahmeberg, C. G., Simons, K., and Kääriäinen, L.: The lipis of the plasma membranes and endoplasmic reticulum from cultured baby hamster kidney cells (BHK 21). Biochim. Biophys. Acta, 255: 65 (1972).

22. Arthur H. Thomas Co., Philadelphia, Pa.

23. Armour Pharmaceutical Co., Chicago, Ill.

24. DC-Fertig Platten Kieselgel $60 \mathrm{~F}_{254}$, E. Merck, Darmstadt, Germany.

25. Amersham, England.

26. Frankfurt/Main, Germany.

27. Calbiochem, Los Angeles, Calif

28. Boehringer and Soehne G.m.b.H., Mannheim, Germany.

29. We thank Miss Ritva Metsola for excellent technical assistance and professor Ossi Renkonen, Ph.D., for helpful discussions.

30. This work was supported by the Foundation for Pediatric Research in Finland.

31. Requests for reprints should be addressed to: K. O. Raivio, M.D., Childrens Hospital, University of Helsinki, Stenbäckinkatu 11 SF-00290 Helsinki 29, Finland.

32. Accepted for publication July 5, 1974

\title{
Total Body Potassium Estimations in Young Children: The Interpretation of Results
}

\author{
M. D. MANN, M. D. BOWIE, (34) AND J. D. L. HANSEN \\ Department of Paediatrics and Child Health, University of Cape Town and Red Cross War Memorial \\ Children's Hospital, Rondebosch, Cape, South Africa
}

\section{Extract}

The whole body counter has provided a fast and accurate method of determining the total body potassium (TBK) of an individual. The interpretation of a single determination does present difficulties because of individual differences in body composition. The normal range, expressed in milliequivalents per kilogram, is so wide that an individual can lose $33 \%$ of his TBK and the result be interpreted as normal. To overcome this problem the prediction of the normal TBK of an individual from functions of weight $(\mathrm{W})$, height $(\mathrm{H})$, and skinfold thickness has been investigated and the accuracy of prediction of TBK and $\log$ TBK by various functions of weight, height, and skinfold thickness compared. Eighty-seven children aged 1.5-27 months and of varying height and weight for age were studied. None had any abnormality which may have resulted in potassium depletion at the time of study. The best prediction of TBK (in milliequivalents or milliequivalents per kilogram) by functions of weight and or height $f(W, H)$ had 95\% tolerance limits of $100 \% \pm 18.2 \%$. Using a function of the 